Sulphide. Crystals of this rare substance have recently been prepared by Mr. F. P. Burt, Eniversity College, London, by sublimation. The constants obtained were $a: b: c=0 \cdot 8879: 10 \cdot 8480: \beta=90^{\circ} 23^{\prime}$, and the observed forms were $(100),(010),(001),(110),(\overline{101}),(011)$, (101), (210), (111), (121), the last four being new. The crystals were invariably characterized by polysynthetic twinning about (101). A biaxial interference figure with strong positive double refraction was visible through (101).-D D. G. T. Prior and Dr. G. F. H. Smith : On a new Arsenate and Phosphate of Lime and Strontia from the Indian Manganese Deposits. Chemical analysis showed that the mineral approximates to the arsenic analogue of apatite. The crystals were not well formed, but the physical characters as far as they could be determined accord with those of apatite. The name fermorite, after Dr. L. L. Fermor, of the Geological Survey of India, who has made an exhaustive study of the manganese deposits, is proposed for this analogue. The presence of strontium, which has not vet been detected in apatite, is of interest.- L. J. Spencer : $\Delta$ (fifth) List of New Mineral Names.

\title{
CORRESPOINDFINOF.
}

\section{A CHELONIAN FROM THE PURBECK OF SWANAGE, DORSET.}

SIR,-In my article on the abore subject (see Grol. MaG. for July, pp. 311-14) the following note was sent in too late for insertion:-

Hooley's Plesiochelys vectensis from the Wealden of the Isle of Wight (Geol. Mag., 1900, p. 263) shows a præneural and seven neurals, instead of eight neurals as suggested in the original description. The specimen probably indicates a new genus.

Seeley's Pleurosternum typocardium, which was insufficiently characterized in his Index to Aves, etc., in the Cambridge Museum, is founded on a specimen of Glyptops ruetimeyeri. It is much more oval in outline than my Fig. 1, a difference possibly partly due to sex, but otherwise shows no new features. The protuberances caused by the crushing through of the axillary and inguinal buttresses are quite evident. Seeley's other species, Pleurosternum sedgwickii, vansittardi, and oweni, appear to be typical examples of $P$. bullocki.

Victoria University, Mavchester.

D. M. S. Watson.

\section{THE TERM 'LATERITE'.}

SIR,-I refuse to plead guilty to the charge advanced by Mr. Scrivenor in your July issue of attempting to force a new definition of laterite on geologists and engineers. I only ask that the word shall be employed for rocks which are chemically and physically allied to that on which it was bestowed by Buchanan.

In dealing with questions of priority of nomenclature we must inquire what was the thing (rock, mineral, or organism, as the case may be) to which the name was first applied, not why it was so applied. Buchanan found a rock widely extended in India which was unlike anything with which he was familiar, and he thought that it 
required a name. As bricks were made of it (not because it resembled a brick) he called it laterite, certainly without intending to include under it all materials of which bricks could be made. I admit that he did not know its true chemical composition, but in spite of that it must be accepted as the type of what we ought to call laterite.

As a matter of fact the majority of geologists and of scientific mining engineers are now using the word in this sense, the sense which I and others are defending, and that this is so a recent discussion in the pages of the Transactions of the Institution of Mining and Metallurgs, in connexion with a paper by $\mathrm{Mr}$. G. Morrow Campbell on the "Origin of Laterite", is sufficient eridence. As to the word 'bauxite' I have no objection to its being applied to a laterite exceptionally poor in silica and iron, and therefore suitable for use as a source of aluminium and its compounds, as long as it is understood that it is so employed as a commercial mineral term and not as a rock name. Scientifically, howerer, it should be restricted to a mineral, if such exist, in which two molecules of water are combined with one of alumina.

We shall all look with interest for the results of Mr. Scrivenor's investigation of the chemical nature of the products of tropical denudation-under whatever name or names he may describe them.

ImPERTAL INSTITUTE. JoHN W. Erass. July 1, 1910.

LATERITE AND BAUXITE.

Sin,-I am glad to learn from Mr. Crook's letter in the May number of the Geological Magazine that I am not alone in holding certain views regarding the term laterite and also the term bauxite, but it is a pity that either side should be led into criticisms that are stronger than the occasion warrants.

I can understand Mr. Crook's surprise that anyone should decline to accept, without question, the new definition of laterite, seeing by what authority it is supported, and I grant that the proposed definition is attractive. But what, in my opinion, has been lost sight of, is that laterite was defined more than a hundred years ago, and that the extension of the term in tropical countries has been based on the early descriptions, the keynotes of which are brick and iron. When an innovation is proposed-for I must with all deference ask still to be allowed to consider this 'aluminous' definition an innovation-the first question is whether it is practicable, the next whether it is necessary. I do not think the change practicable, because the ideas of brick and iron have taken firm root and have led to the term being widely used for ferruginous rocks, useful in public works and in building. As its practicability is denied there is no question of its necessity; but were the change practicable, would the new be better than the old definition? The brick and iron characteristics are easily recognized; the aluminous is not. The word 'laterite' has no etymological connexion with aluminium; it has with brick, and so, indirectly, with iron, since the setting of laterite is dependent, mainly at any rate, on the presence of ferric hrdroxide. Both Dr. Evans and 